\title{
Nine for Peace
}

\section{MENNA ELFYN}

translated from the Welsh by Robert Minhinnick

'Catonsville nine' peace activists including poet-priests

Daniel and Philip Berrigan, May 17th 1968, Maryland

Because if this seems disruptive-

comrades we apologise-

incinerating draft papers

instead of infants

with our home-made napalm

because with Vietnam

such a bloody conflagration

we think it's imperative

Because we shared the Lord's Prayer

quietly before court-

our shackles ensuring silence

no-one should pity us

because we slept that night

dreaming a desert of ashen earth

Because we nine pledged

with heaven on earth our plea

each voice a step closer to peace

because countless went to war

towards sunset without sanctuary

restless and unrecorded

honest folk ripped away from their roots

because men can be vicious

our language teems with violent verbs

but trust the poet

to spoil death's party

using words that challenge war's hardware

and memories of its maiming

Because hellfire we must learn

is more than a missile

but such is its accursedness

that its lesson leaves us no choice 